\title{
Minerva
}

\section{NUCLEAR ENERGY IN THE PUBLIC SPHERE: ANTI-NUCLEAR MOVEMENTS VS. INDUSTRIAL LOBBIES IN SPAIN (1962-1979).

\author{
--Manuscript Draft--
}

\begin{tabular}{|c|c|}
\hline Manuscript Number: & MINV-D-13-00057R1 \\
\hline Full Title: & $\begin{array}{l}\text { NUCLEAR ENERGY IN THE PUBLIC SPHERE: ANTI-NUCLEAR MOVEMENTS VS. } \\
\text { INDUSTRIAL LOBBIES IN SPAIN (1962-1979). }\end{array}$ \\
\hline Article Type: & Article \\
\hline Keywords: & $\begin{array}{l}\text { Nuclear industry; antinuclear movement; Spanish Atomic Forum; Franco regime; } \\
\text { Spain. }\end{array}$ \\
\hline Corresponding Author: & $\begin{array}{l}\text { Luis Sánchez-Vázquez, Ph.D. } \\
\text { Technical University of Loja } \\
\text { ECUADOR }\end{array}$ \\
\hline \multicolumn{2}{|l|}{$\begin{array}{l}\text { Corresponding Author Secondary } \\
\text { Information: }\end{array}$} \\
\hline Corresponding Author's Institution: & Technical University of Loja \\
\hline \multicolumn{2}{|l|}{$\begin{array}{l}\text { Corresponding Author's Secondary } \\
\text { Institution: }\end{array}$} \\
\hline First Author: & Luis Sánchez-Vázquez, Ph.D. \\
\hline \multicolumn{2}{|l|}{ First Author Secondary Information: } \\
\hline \multirow[t]{2}{*}{ Order of Authors: } & Luis Sánchez-Vázquez, Ph.D. \\
\hline & Alfredo Menéndez-Navarro, Ph.D. \\
\hline \multicolumn{2}{|c|}{ Order of Authors Secondary Information: } \\
\hline Abstract: & $\begin{array}{l}\text { This article examines the role of the Spanish Atomic Forum as the representative of the } \\
\text { nuclear sector in the public arena during the golden years of the nuclear power } \\
\text { industry from the 1960s to 1970s. It focuses on the public image concerns of the } \\
\text { Spanish nuclear lobby and the subsequent information campaigns launched during the } \\
\text { late } 1970 \text { s to counteract demonstrations by the growing and heterogeneous anti- } \\
\text { nuclear movement. } \\
\text { The role of advocacy of nuclear energy by the Atomic Forum was similar to that in } \\
\text { other countries, but the situation in Spain had some distinguishing features. Anti- } \\
\text { nuclear protest in Spain peaked in } 1978 \text { paralleling the debates of a new National } \\
\text { Energy Plan in Congress, whose first draft had envisaged a massive nuclearization of } \\
\text { the country. We show how the approval of the Plan in July } 1979 \text {, with a significant } \\
\text { reduction in the nuclear energy component, was influenced by the anti-nuclear protest } \\
\text { movements in Spain. Despite the efforts of the Spanish Atomic Forum to counter its } \\
\text { message, the anti-nuclear movement was strengthened by reactions to the Three } \\
\text { Miles Island accident in March } 1979 \text {. }\end{array}$ \\
\hline
\end{tabular}




\section{Authors:}

Luis Sánchez-Vázquez (1) and Alfredo Menéndez-Navarro (2)

Title:

NUCLEAR ENERGY IN THE PUBLIC SPHERE: ANTI-NUCLEAR MOVEMENTS VS. INDUSTRIAL LOBBIES IN SPAIN (1962-1979).

\section{Author affiliations:}

(1) Observatorio de Conflictos Socioambientales/Department of Social Sciences/ Technical University of Loja (UTPL). San Cayetano Alto. 1101128 - Loja - Ecuador

(2) Department of History of Science. University of Granada. Avda. de Madrid 11, 18012 Granada, Spain

\section{Corresponding author:}

Luis Sánchez Vázquez

Email: lsanchez3@utpl.edu.ec

Phone: 00593-7-2570275 ext. 2631

Fax: 00593-7-2584893 


\section{Authors:}

Luis Sánchez-Vázquez (1) and Alfredo Menéndez-Navarro (2)

\section{Title:}

NUCLEAR ENERGY IN THE PUBLIC SPHERE: ANTI-NUCLEAR MOVEMENTS VS. INDUSTRIAL LOBBIES IN SPAIN (1962-1979).

\section{Author affiliations:}

(1) Observatorio de Conflictos Socioambientales/Department of Social Sciences/ Technical University of Loja. San Cayetano Alto. 1101128 - Loja - Ecuador

(2) Department of History of Science. University of Granada. Avda. de Madrid 11, 18012 Granada, Spain

\section{Corresponding author:}

Luis Sánchez-Vázquez

Email: 1sanchez3@utpl.edu.ec

Phone: 00593-7-2570275 ext. 2631

Fax: 00593-7-2584893 


\begin{abstract}
This article examines the role of the Spanish Atomic Forum as the representative of the nuclear sector in the public arena during the golden years of the nuclear power industry from the 1960s to 1970s. It focuses on the public image concerns of the Spanish nuclear lobby and the subsequent information campaigns launched during the late 1970s to counteract demonstrations by the growing and heterogeneous anti-nuclear movement.

The role of advocacy of nuclear energy by the Atomic Forum was similar to that in other countries, but the situation in Spain had some distinguishing features. Anti-nuclear protest in Spain peaked in 1978 paralleling the debates of a new National Energy Plan in Congress, whose first draft had envisaged a massive nuclearization of the country. We show how the approval of the Plan in July 1979, with a significant reduction in the nuclear energy component, was influenced by the anti-nuclear protest movements in Spain. Despite the efforts of the Spanish Atomic Forum to counter its message, the anti-nuclear movement was strengthened by reactions to the Three Miles Island accident in March 1979.
\end{abstract}

Keywords: Nuclear industry, anti-nuclear movement, Spanish Atomic Forum, Franco regime, Spain.

\title{
Introduction
}

The atomic debate erupted into the public sphere of Western countries during the 1960s and 1970s with confrontations between anti-nuclear activists and pro-nuclear associations. Waves of anti-nuclear protest spread rapidly in countries that had invested heavily in nuclear programs to meet the energy crisis in 1973. Public perception of nuclear power was becoming increasingly negative, and the term nuclear evoked widespread fears about accidents, radioactivity or bombs. In this context, the future of nuclear was highly dependent on public and political acceptance. Pro-nuclear coalitions were mainly composed of nuclear scientists and engineering firms, electric utilities, nuclear plant manufacturers, and agencies promoting nuclear power, i.e., the so-called "Atomic Industrial Establishment" (Lewis 1972). During the 1950s, Industrial Nuclear Forums were founded by pro-nuclear lobbies in countries utilizing or developing nuclear power. Their aim was to communicate favorable information on specific projects and on nuclear power in general in order to enhance the credibility of the nuclear industry and improve its public acceptance.

The main goal of this study was to analyze the role played by the nuclear industry in Spain during the 1960s and 1970s in the context of a growing antinuclear movement and increasing concerns among the general population. There is a wide historiography on the introduction and development of nuclear energy in Spain, but it has mainly addressed political, military, or technological issues (Presas i Puig 2005, Romero and Sánchez-Ron 2001; Ordóñez and Sánchez-Ron 1996). Research has also focused on anti-nuclear activity in Spain during the final years of Franco regime (Costa 1976; Fernández 1999; López Romo 2008; López Romo and Lanero Táboas 2010). However, little attention has been paid so far to the role of the industry itself in the development of nuclear power in Spain or to the actions taken to counteract the rising anti- 
nuclear movement in the 1960s and 1970s.

In a first attempt to fill this historiographical gap, we focused on the Fórum Atómico Español (Spanish Atomic Forum, hereafter FAE), the industrial association that promoted the interests of the nuclear sector in Spain. We sought to identify and clarify the main arguments of the nuclear sector in the Spanish public arena by analyzing the abundant material published by the FAE during the period from 1962 through 1979, starting with the setting up of the FAE and ending after the Three Miles Island (hereafter TMI) accident. We shall also discuss the relevance of the accident in Harrisburg as a significant turning point in Spanish public opinion on the nuclear industry.

We focus on the last years of this period, 1977 to 1979, which coincided with the discussion of a new National Energy Plan (hereafter NEP) in Congress, with some important local protests, and with the TMI accident. We completed our study of trends in Spanish public opinion by analyzing pro-nuclear and antinuclear discourses in two leading newspapers of the time, $A B C$ and $E l$ País, and in two of the most important regional newspapers, La Gaceta del Norte and El Periódico de Catalunya.

\section{Anti-nuclear movements in the decades of protest}

The 1960s were marked by public discontent organized in different types of protest movement, including the anti-nuclear wing of the environmentalist movement, the feminist movement, and the peace movement, with a varying degree of interactions among them (Kriesi et al. 1995: 8; Giugni 2004: 44-45). However, although the 1960s have usually been perceived as the decade of protest, it was the 1970s in which a wide variety of social movements entered the public arena (Freeman and Johnson 1999: 5). They maintained most of the structural goals underlying their creation during the 1960s, but their concerns and strategies changed in accordance with the new times.

The anti-nuclear movement provides a good illustration of this development. Nuclear power has always been controversial, and the distrust of the population and their gradual resistance were already manifest by the mid-1950s, mainly in protests by peace and nuclear disarmament movements against the hazards of nuclear weapons testing and their effects on the environment and neighboring populations (Taylor, 1994). Nevertheless, public awareness of nuclear risks was not widespread until the expansion of nuclear power programs during the 1960s, when many more communities were affected by siting proposals (Surrey and Hugget 1976; Rudig 1990).

The construction of nuclear power plants was promoted with particular intensity by governments during the 1973 energy crisis to reduce their dependence on oil and supposedly provide a cheap source of electricity. This development was led by the USA nuclear industry. In early 1973, the American Energy Commission (hereafter AEC) predicted a huge increase in nuclear capacity, with industry executives talking of "a net increase in utility commitment to nuclear power" and "the virtual collapse of competition from fossil fuels" (Walker 2006: 7-8). Several citizens' groups emerged to confront the expansion of the nuclear industry, and the 1970s saw a shift in the anti-nuclear movement toward protests against the development of 
nuclear power as a source of energy. The nuclear power conflict became described as one of the most intense controversies in the history of technology (Kitschelt 1986: 57).

Anti-nuclear movements pursued distinct strategies and had a different impact on overall energy policy in each national case, depending on the political opportunity structure of the country in question (Kitschelt 1986: 57-85; Shawki 2010: 383-385). ${ }^{1}$ However, they all shared a number of common features that shaped the anti-nuclear struggle: a previous protest movement against nuclear weapons testing and against radioactive pollution; a rapid rise in environmental concerns during the 1960s; a movement towards greater social responsibility in science; and new cultural and political values opposed to the economic system and energy growth. ${ }^{2}$ Most of these concerns were also important to environmentalist and pacifist movements, but the anti-nuclear movement was distinguished by its focus on the specific risks of nuclear power, including the large-scale effects of a potential accident, the possibility of long-term mortality from cancer, the potential genetic effects on future generations, and the association between nuclear power and nuclear weapons (Surrey and Hugget 1976: 286-288; Rudig 1990).

The opposition to nuclear power was greater than expected, especially in Europe. In France, the first two decades of nuclear development took place in an atmosphere of political consensus, free from any public opposition until the early 1970s, ${ }^{3}$ Nevertheless, there were strong anti-nuclear protests against new siting proposals, especially in Fessenheim (1971) and Marckolsheim (1974) on the German border. A wave of protest rapidly spread to Germany and Switzerland, helped by the political opportunities presented in both countries through mass mobilizations for regional claims (Kriesi et al. 1995: 181).

Anti-nuclear protests were connected across Europe, with the different movements imitating successful tactics employed in other countries (Kriesi et al. 1995; Taylor, 1994; Rudig 1990; Falk 1982; Mills and Williams 1986). They argued for a slowing in the growth of energy consumption and for the development of other energy sources, emphasizing the need for safeguards in relation to the transport, reprocessing, and disposal of radioactive materials (Surrey and Huggett 1976: 297-298; Rudig 1990: 112130). Major demonstrations against government nuclear plans took place in different countries during the 1970s. The successful "Whyl experience" in Germany ${ }^{4}$ encouraged other mobilizations throughout Europe,

\footnotetext{
1“Political opportunity structures are comprised of specific configurations of resources, institutional arrangements, and historical precedents for social mobilization, which facilitate the development of protest movements in some instances and constrain them in others." (Kitschelt 1986: 58).

${ }^{2}$ While we can find some similarities between the protests in Europe and the USA, Japan represents a particular case. The bombs in Hiroshima and Nagasaki, the severe seismic conditions and the Bikini incident produced a complex and conflictive scenario around nuclear energy in Japan. The anti-nuclear opposition in Japan has been widely discussed by several authors, who have described the different facets of the Japanese anti-nuclear movement. For instance, Akaha (1985: 75-89) reports the influence of the anti-nuclear movement in the parliamentary resolution that has guided Japanese nuclear policy since the late 1960s, known as the "three nonnuclear principles"; while Higuchi emphasizes the environmentalist origins of the Japanese anti-nuclear movements against the centrality of Hiroshima and Nagasaki within this activism (Higuchi 2008). Nevertheless, there is a wide consensus about the major importance of the movement against nuclear tests in the mid-1950s, and more than one-third of the Japan population had signed a petition to ban nuclear tests by the summer of 1955 (Yamazaki 2009: 132-145).

${ }^{3}$ Political, economic and labor representatives worked together to rebuild the national industry complex, and they agreed in the creation of a new electric utility (Electricité de France) and the atomic energy commission, strongly supported by De Gaulle (Hetch 1996: 486-488).

${ }^{4}$ Wyhl, a small village in the southwestern corner of Germany, was proposed in 1971 as a possible site for a nuclear power station. In the years that followed, the incipient local opposition had little impact on politicians and planners. Official permission for the plant was granted and earthworks began on February 171975 (Patterson 1986: 113). Just the day after, local people spontaneously
} 
including strong protests in Austria, Switzerland, France, and Spain (Mills and Williams 1986: 375-376).

Among the numerous local anti-nuclear protests in the USA during the 1970s, some captured public attention at a national level, including activities by the Clamshell Alliance protests at Seabrook Station Nuclear Power Plant and by the Abalone Alliance at Diablo Canyon Nuclear Power Plant. After the 1979 TMI accident, protests spreads around the country, and 65,000 people joined a large demonstration against nuclear power in Washington D.C. in May 1979 (Giugni 2004: 44-45).

\section{The backlash: Reaction of the industrial lobbies}

During the post-war years and the Cold War, the positive perception and acceptance of nuclear power was influenced by propaganda techniques and communication campaigns targeting public opinion. The best example was the Atoms for Peace program developed by the Eisenhower administration (Krige 2006; Weart 1988; Hewlett and Holl 1989; Forgan 2003).

When the civil atomic programs started in the 1950s, they were led by different governmental nuclear agencies and involved both private and public investment (Hewlett 1990). The US Atomic Industrial Forum (hereafter AIF) was created in 1954 and represented more than 400 companies and private corporations in the nuclear field by 1956. In the United Kingdom, the British Nuclear Energy Society and the Institution of Nuclear Engineers began to serve the industry and represent its interests in 1956, a few years after the British nuclear industry first came into being (British Nuclear Energy Society 1956). During the late 1950s, following the creation of the AIF, several industrial associations were established in Europe, such as the Deutsches Atomforum in Germany; the Forum Atomique Français in France and the Forum Italiano Dell'Energia Nucleare in Italy. The European Atomic Forum, Foratom, the Brussels-based trade association for the nuclear energy industry in Europe, was founded in 1959 (Caro et al. 1995: 398).

After the first substantial opposition to a planned reactor in the 1950s in the USA (Goodman 1961), leaders of the industry started to become worried about a hazard that was new for them. ${ }^{5}$ By 1969 , the AIF's Public Affairs and Information Committee was alarmed about the rising anti-nuclear movements and about the growing national press coverage of the issue. ${ }^{6}$ During the early 1970s, even some of the most aggressive promoters of nuclear energy at the political level took serious note of the environmental concerns and antinuclear opposition. Several states proposed more restrictive environmental legislation for nuclear sites

occupied the site and the police used force to remove them two days later, on February 20. Television coverage of the rough treatment of the local farmers by the police contributed to turn nuclear power into a major national issue (Fach and Grande 1992: 20). Subsequent support came from the university town of Freiburg, when about 30,000 people re-occupied the Wyhl site on February 23. The Wyhl occupation and the subsequent demonstration in Freiburg generated extensive debate in Germany and, on March 211975 an administrative court withdrew the construction license for the plant (Rudig 1990: 130-135; Mills and Williams 1986: 375-376; Gottlieb 2005: 237). The plant was never built and the land eventually became a nature reserve. The importance of the Wyhl experience in encouraging the emergence of local and regional grassroots activism has been highlighted (Mills and Williams 1986: 375-376; Rudig 1990). The growing protest after the Whyl conflict has been described as a prelude to the "sudden death" of the nuclear program in the late 1970s (Fach and Grande 1992: 20-21). Anti-nuclear success at Wyhl also inspired nuclear opposition in the rest of Europe and North America (Patterson 1986: 113; Gottlieb 2005: 237; Rudig 1990: 130-135).

${ }^{5}$ The members of the AIF and the insurance companies pointed out that the risks associated with fuel production, reprocessing and waste storage were as great in the long term as those associated with the reactors. See Damian (1992: 606).

${ }^{6}$ The Chair of this Committee cited the article "The nukes are in hot water", published in 1969 by Sports Illustrated, as the first indication of this change (Balogh 1991: 264). 
(Balogh 1991: 265-285). Consequently, the AIF and the energy-utility complex focused their efforts on the delegitimization of the anti-nuclear movement rather than on a public debate about nuclear hazards. ${ }^{7}$

The best example of this public struggle was "Proposition 15" in the California election in June 1976. The Proposition called for stricter legislative regulation of the nuclear power industry, and inspired six similar ballots in other states and in Switzerland. Representatives of the industry feared that success of the Proposition would have an anti-nuclear domino effect (Wellock 1998: 149). The nuclear industry in the USA, led by the AIF, made available a large number of documents arguing the pro-nuclear case. They mainly highlighted the possible economic effects of a nuclear moratorium, the environmental problems of coal mining, and the illegality of the Proposition (Kenward 1976). Notwithstanding the eventual rejection of the Proposition, it was perceived by the nuclear industry as a bittersweet victory because it had contributed to a gaining of momentum and influential support for the anti-nuclear movement (Wellock 1998: 332).

By the early 1970s, the electric companies were finding it increasingly difficult to obtain project licenses, and several projects in Europe and Japan had been withdrawn by 1972 due to local opposition (Young 1983: 1-16). Support for nuclear power was led by the national industrial associations, which launched various communication campaigns highlighting the need for nuclear power in the context of an energy crisis. These campaigns detailed the high safety standards in nuclear industry and promoted consultation processes and public discussions with representatives of local communities, unions, and other civil associations affected by siting proposals (European Nuclear Society 1979; Surrey and Hugget 1976: 299-300; Hetch 1996: 488-489; Yamazaki 2009: 137-138.). In Spain, they also played on fears of becoming over-dependent upon oil and emphasized the presence of uranium reserves in the country (Sánchez-Vázquez 2012: 77-78).

By the late 1970s, every country with a commercial nuclear program had experienced its own antinuclear reaction with specific national characteristics. Advocates of nuclear energy were surprised by the intense public opposition to the large scale application of this energy source. However, the experience drawn from public hearings, debates, and face-to-face discussions with representatives of the anti-nuclear movements made them aware "of modes of thought and criteria of judgment that they had not previously encountered" (Häfele 1974: 303).

\section{The nuclear industry in Spain (1962-1976)}

The importance of the military nature of Franco regime in shaping the early Spanish interest in nuclear technology (Presas i Puig 2005; Ordóñez and Sánchez-Ron 1996) was consolidated by the discovery and exploitation of uranium deposits in Spain in the early 1950s. ${ }^{8}$ Eisenhower's Atoms for Peace Program ${ }^{9}$ and

\footnotetext{
${ }^{7}$ As it was put by Frank Shants, special project manager of the New Hampshire Public Service Company "Instead of trying to arouse the public for nuclear power, we should change course and try to arouse the public against the antinuclear groups ...” (Davidon 1979: 46).

${ }^{8}$ Spain began its own production of uranium on an industrial scale, becoming the third country in Europe, after United Kingdom and France, with a pilot chemical treatment plant (Caro et al. 1995: 50-56).

${ }^{9}$ The Spanish case shows the propaganda facet of the Atoms for Peace programme to perfection (Weart, 1988: 162-165). On July 1955, USA and Spain signed an agreement in Washington D.C. for cooperation "concerning civil uses of atomic energy". The
} 
the First International Conference on the Peaceful Uses of Atomic Energy have been acknowledged as relevant factors encouraging the Spanish government to develop a Spanish nuclear power industry. ${ }^{10}$ The opening of the Spanish market to private American companies involved in the construction of power reactors was effectively promoted in this context.

In the 1960s, there was a change in Spanish economic and social situation and an opening up to the outside world. Agreement was reached between the main Spanish political force, the falangists (nationalists), and the new technocrats on the need to encourage the development of nuclear energy. This agreement allowed "one of the poorest countries in Western Europe to enter the exclusive club of nuclear producing countries" (De la Torre and Rubio 2014: 2). However, while the falangists supported nuclear energy as a means of strengthening Spanish autonomy, the technocrats saw it as the best means to liberalize the national economy and promote the involvement of private companies in nuclear power production. The nationalist line was backed by the National Institute of Industry (Instituto Nacional de Industria, INI) headed by Juan Antonio Suanzes. The INI diverged from the official policies on nuclear power presented by the Nuclear Energy Board (Junta de Energía Nuclear, JEN), the governmental agency responsible for all aspects of nuclear management until the 1960s, when private industry started to gain importance in Spanish nuclear development (Romero and Sánchez-Ron 2001: 123-150; Gómez Mendoza 2007: 551-553; Sánchez-Vázquez 2012: 68-70).

These conflicts and divergences within the Spanish Government during the late 1950s are crucial for an understanding of this process. Faced with the obstructionist attitude of the INI, the JEN and the private companies adopted a policy of active cooperation at the experimental and technological level, supporting the proposals of the technocrats (Gómez Mendoza 2007: 551).

Hence, the technocratic argument prevailed over the nationalist view, because the gradual international integration of the country made it easier for the Spanish industry to acquire foreign technology and buy nuclear reactors "keys-in-hand" (Presas i Puig 2005: 210-214; Romero and Sánchez-Ron 2001: 195201), although some major figures in the regime complained about Spain's self-imposed dependence on foreigners and its inappropriate industrial strategy (Presas i Puig, 2005: 214-215). This change in the attitude of the government can also be interpreted in the context of a new phase in global nuclear development, which demanded a new organization system focused on commercial reactors, as reported in other national cases $^{11}$. In so doing, the leadership of the Spanish nuclear sector started to be transferred from the governmental Nuclear Energy Board to private industry (Presas i Puig 2009; Sánchez-Vázquez 2010: 85-90),

\footnotetext{
agreement made it clear that the USA effectively controlled nuclear matters in Spain through the AEC. It also pointed out that "private organizations in either the USA or Spain may deal directly with private individuals and private organizations in the other country (Ordóñez and Sánchez-Ron 1996: 195-196).

${ }^{10}$ The favorable climate of opinion in the Conference, as well as the estimations for the consumption of electricity in the sixties, pointed clearly to nuclear power as a solution, even when its economic viability remained controversial. (Weart 1988: 158; Barca Salom 2005: 163-181).

${ }^{11}$ This model was based on linking together certain economic sectors, including infrastructure construction, electrical and metallurgical materials, and financing [banks, insurance]. It also reinforced commercial relationships with the United States (and to a lesser extent with Germany and France), which strengthened the military and geo-strategic position of Spain in the Western world (Romero and Sánchez-Ron 2001: 201; De la Torre and Rubio 2013: 2-3).
} 
contributing to create what has been called the Spanish version of the "Nuclear Iron Triangle"12, which brought together politicians from the government, technicians and scientists from the Nuclear Energy Board, and representatives from private companies (De la Torre and Rubio 2014: 16).

The Spanish nuclear industry "boom" began in 1963, when a newly founded company, Nuclenor, was licensed to build a nuclear power station in Santa María de Garoña, Burgos. The reactor was purchased "keys-in-hand" from General Electric. Simultaneously, the company Cenusa applied for permission to build a new power plant in Zorita, Guadalajara, which, in 1968, became the first to be successfully completed and operative in Spain. The reactor was purchased from Westinghouse (Romero de Pablos, 2012: 49-54; Caro et al. 1996: 355-360). In 1972, the newly founded nuclear company Hifrensa ${ }^{13}$ constructed the Vandellós I plant (Tarragona) using French technology based on natural uranium. In 1971 and 1972, six new 930 MW reactors were purchased from Westinghouse: Almaraz I and II; Lemóniz I and II, which were never completed; and Ascó I and II (Romero de Pablos, 2012: 55-58; Romero and Sánchez-Ron 2001: 254-260).

The energy crisis of 1973 brought a review of energy requirements and gave renewed impetus to the demand for nuclear power, as reflected in the first NEP of 1975. Eleven more stations were planned between 1973 and 1976, but only four were finally completed (Sánchez-Vázquez 2010: 282-286). While there was little participation by Spanish industry in the first three power plants (Burgos, Guadalajara, and Tarragona), this situation changed with the new power plants built in the 1970s, when up to $80 \%$ of projects were in the hands of private Spanish companies (Presas i Puig 2005: 217).

\footnotetext{
${ }^{12}$ Expression used by Brian Balogh for the Nuclear Program in the United States (Balogh, 1991).

${ }^{13}$ Hispano Francesa de Energía Nuclear, formed by three electrical companies from Catalonia (Fecsa, Enher and Hidroeléctrica de Cataluña) and Electricité de France (EDF) (Anes et al 2001:47).
} 


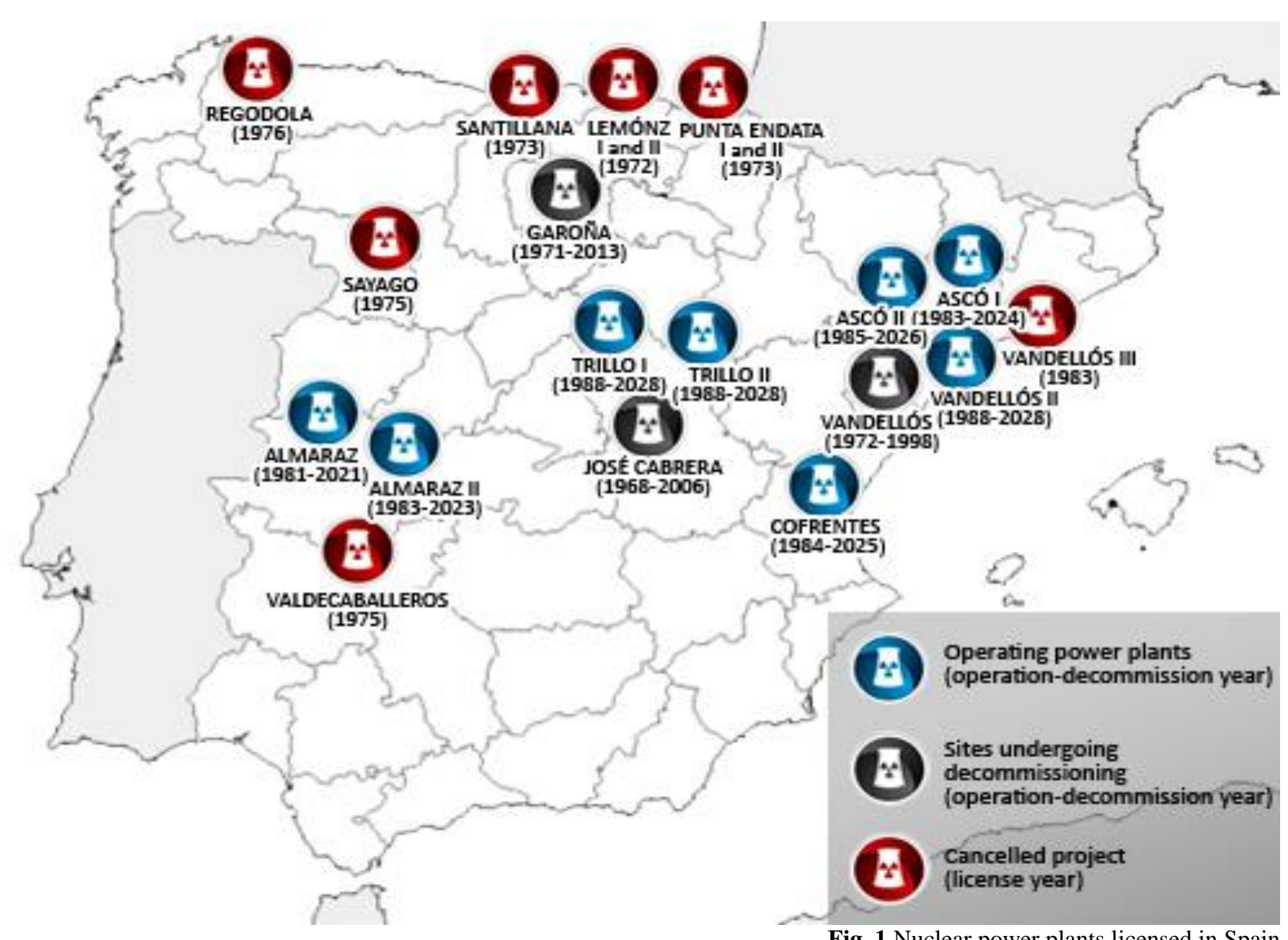

Fig. 1 Nuclear power plants licensed in Spain

Paralleling this nuclear boom, the FAE was founded in 1962 to bring together industries involved in the nuclear sector and to increase their penetration of the Spanish energy market (Fórum Atómico Español 1962: 2-10). The 50 founding companies included the main electric companies in Spain (i.e., Hidroeléctrica Española, Iberduero, Electra de Viesgo, Endesa, Hidroeléctrica del Cantábrico, Unión Eléctrica Madrileña, Compañía Sevillana de Electricidad, and Hidroeléctrica de Cataluña), new companies established to manage Spanish nuclear facilities (i.e., Cenusa and Nuclenor), manufacturers of nuclear components and systems (i.e., Construcciones Nucleares and Sociedad Española de Construcciones Babcock y Wilcox), private engineering companies (i.e., Tecnatom and Estudios y Proyectos Eléctricos), the Spanish Nuclear Energy Board, insurance companies (i.e. Unión Iberoamericana and La Estrella), and a bank (Banco de Vizcaya) (Fórum Atómico Español 1962: 18-20).

Apart from acting as the voice of the industry in energy policy discussions and promoting the commercial uses of nuclear energy, FAE's specific objectives and emphases changed over time to meet the needs of the sector. During the 1960s, FAE's major concerns were the promotion of commercial nuclear power, the development of different technical aspects, and integration within Foratom, aimed at gaining influence in the European setting. To meet this last objective, the FAE set up several study groups to support the work of Foratom in specific tasks. During the celebration of the First Nuclear Conference organized by the FAE and held in Madrid in 1963, the Foratom Executive Committee held its first meeting in Spain to discuss the role of FAE in the organization. The president of the FAE, José María Oriol, was named vice- 
president of Foratom in 1964 and became president of the organization in 1966, strengthening the influence of the FAE in the European nuclear field during the late 1960s (Caro et al. 1996: 398-399).

In this context of euphoria for the Spanish nuclear sector, changes in Spanish socio-political situation brought the public relations aspect into prominence during the early 1970s (Romero and Sánchez-Ron 2001: 260; Sánchez-Vázquez 2010: 85-90).

\section{The late anti-nuclear awakening in Spain: From Palomares (1966) to the "Long Anti-nuclear March"} (1974-1977)

During the 1960s, social opposition to nuclear energy was almost an irrelevant issue in Franco's Spain, attributable to the prohibition by the powerful repressive system of any expression of opposition or questioning of the regime's policies (Ysás 2007: 32). FAE's activities during this decade showed a remarkable lack of concern about public opinion in comparison to the European or American cases. This position did not even change after the so-called "Palomares incident" in 1966, one of the most high-profile accidents involving American nuclear weapons outside the USA. On January 17 1966, a USAF B-52G bomber collided with a KC-135 tanker during mid-air refueling off the coast of Spain. Out of the four Mk28 type hydrogen bombs lost by the bomber, three were found on land near the small fishing village of Palomares in Almería, Southern Spain. The non-nuclear explosives in two of the bombs detonated upon impact, contaminating an area of two square kilometers with radioactive plutonium. The fourth bomb, which fell into the Mediterranean Sea, was recovered intact after a 12-week search (Megara 2006; Ordóñez and Sánchez-Ron 1996: 212).

Spanish government applied its usual propaganda methods to defuse possible social alarm about environmental pollution. Spanish Official Newsreel NO-DO, which was the main source of visual information for Spaniards up to the late 1960s, covered a swim by the Minister of Tourism Fraga Iribarne and the US ambassador Angier Biddle Duke at Palomares beach in March 1966, which became an enduring image of nuclear power in Franco's Spain. Nevertheless, the incident became the starting point for structured and visible opposition to nuclear energy in Spain (Sánchez-Vázquez 2010: 218-229).

There is a surprising lack of references to the incident in FAE publications. Up to this point, almost all references in FAE publications about anti-nuclear demonstrations or public opinion came from abroad. ${ }^{14}$ This could be attributed to the immaturity and lack of developed structure of the anti-nuclear movement in Spain and to the government support for the sector, but it may also reflect a conscious strategy of the nuclear lobby to invisibilize the movement.

However, in response to the considerable number of new nuclear power plants planned in the first NEP in 1975, a strong anti-nuclear movement emerged in the 1970s in Spain, which ultimately prevented the completion of most of the projects. All of the local and regional demonstrations against the new planned stations became known as the Long Anti-Nuclear March (Larga marcha antinuclear) (Fernández 1999: 119-

\footnotetext{
${ }^{14}$ In the Boletines Informativos of 1966, periodicals edited by the FAE during that year, there is a total lack of references to the incident (Fórum Atómico Español, 1966a to 1966e).
} 
129). The first protest actions began in 1974 in the Basque Country and Navarra against projects in EaIspaster, Deba, and Tudela (López Romo and Lanero Táboas 2010; López Romo, 2008). Several heated demonstrations took place in the affected regions during 1975, and power plant projects in Sástago and Escatrón (Aragón); Xove (Galicia); Tarifa and Doñana (Andalusia), and Águilas (Murcia) were withdrawn (Costa 1976: 50-75).

Given the political situation in Spain during the 1970s, it would not be accurate to refer to a homogeneous "Spanish" anti-nuclear movement. The anti-nuclear protests were closely linked to nationalist and pro-independence movements in regions like Catalonia, the Basque Country or Galicia, which influenced the shaping and development of these protests (Mora Ticó 2012; López Romo and Lanero Táboas 2010; López Romo, 2008). In fact, the proliferation of discourses and collective actions of opposition to nuclear power plants became a valuable tool for nationalist movements to expand their presence in the public arena in terms of the political opportunities presented by mass mobilizations. In other Spanish regions, the arguments against nuclear power were posed in non-nationalist terms, and the protests contributed to strengthening the associative movement and the demands for democracy (López Romo and Lanero Táboas 2010: 751-752).

In order to coordinate and draw together these regional mobilizations, a national organization was created in Soria in May 1977: the Anti-nuclear State Coordinator (Coordinadora Estatal Antinuclear, hereafter CEA). It was driven by such organizations as the Anti-Nuclear Committee of Catalonia (Comité Antinuclear de Cataluña), or the Defense Committee for a Non-Nuclear Basque Coast (Comisión de Defensa de una Costa Vasca No Nuclear). CEA did not have a stable structure or a fixed membership for organizations, which were able to join and leave freely. It usually met three times a year, with periods of higher and lower frequency (Cabal 1996; Bigas 1991: 91-99). The structural demands of the anti-nuclear protest included the call for democracy, in common with other Spanish social movements of the time. During this period, from Franco's death in 1975 to the first democratic elections in 1977, civil society in Spain experienced a turbulent and exciting time and anti-nuclear movements reached their peak (Preston 1986: 6072; Ysás 2007).

FAE's publications included several statements by representatives of the industry and nuclear institutions that expressed confidence in government support but also evidenced some disquiet about the outbreaks of unexpected opposition. This increasing anxiety is reflected in the topics chosen for FAE conferences and lectures. By 1977, the Spanish nuclear sector was fully aware of the problems related to the anti-nuclear movement. ${ }^{15}$ The Annual Nuclear Symposium organized by the FAE that year included a session devoted to "Nuclear Energy and Public Opinion", in which Spanish nuclear industry representatives described their increasing concerns about the public reaction (Fórum Atómico Español, 1977c).

\section{Lemóniz conflict, the drafting of the second National Energy Plan and the reaction of the Spanish}

\footnotetext{
${ }^{15}$ As reflected in periodicals published during 1976 and 1977, which started to express the increasing worries of the sector (Fórum Atómico Español, 1976, 1977a, 1977b).
} 


\section{Atomic Forum (1978)}

Two major anti-nuclear events took place in Spain in 1978: conflict around the Lemóniz Nuclear Power Plant in the Basque province of Vizcaya and mobilizations in advance of the approval of the second NEP in July 1979. The building of the power station in Lemóniz was opposed by ETA, the paramilitary Basque independence organization, as well as by the anti-nuclear organization the Defense Committee for a NonNuclear Basque Coast and several anti-nuclear local committees created in different towns (López Romo 2008: 13). They pointed to the lack of an operating license by Iberduero (the company in charge) and highlighted the hazards of nuclear waste (La Gaceta del Norte 1976a; López Romo 2011). In August 1976, a massive demonstration against the power plant took place near Plentzia and Górliz, two small towns near Lemóniz $^{16}$. On December 18 1977, an ETA commando unit attacked a Guardia Civil post guarding the station, and one of the unit, was injured in the attack and died a month later. On March 17 1978, ETA planted a bomb in the reactor of the station, leaving two workers dead and more than a dozen injured (López Romo 2008; La Gaceta del Norte 1978a). The explosion also caused substantial material damage to the facility ${ }^{17}$, forcing Iberduero to delay its construction (Mez et al. 2009: 371; López Romo 2011). The outbreak of violence and the deaths prompted considerable condemnation in the regional press (La Gaceta del Norte 1978b) and provoked intense debate within the Basque anti-nuclear movement (López Romo 2008: 16).

It was under these conflictive circumstances that the discussion on the second NEP took place, bringing the nuclear issue to the forefront of public debate. The second NEP resulted from political agreements reached during the so-called Pactos de la Moncloa (Moncloa Pacts) in 1977, which involved all democratic political forces in Spain committed to a stable transition to a democratic system (Cuerdo 1999: 165). The first draft of the second NEP proposed a significant increase of $37.7 \%$ over the nuclear power supply proposed in the first NEP (Ministerio de Industria y Energía 1978). The anti-nuclear movement reacted to this nuclearization proposal with intense demonstrations, and demands for a moratorium were included in the political programs of the Socialist (PSOE) and Communist (PCE) Spanish parties. These political pressures forced the Ministry of Industry to draw up an alternative NEP. The media were paying increasing attention to the arguments around energy policy, and the energy sector and the FAE contracted public relations agencies in order to strengthen its position in the public debate (El País 1978a).

The redrafting of NEP was highly controversial, even within the Spanish government. It caused an open confrontation between the Ministries of Industry and Economy. The Minister of Industry and his team were radically opposed to Minister of Economy's proposal for the nationalization of all nuclear plants built after 1987 (El País 1978b). Based on new projections for future energy demand and the availability of local resources (coal and hydraulic power), the second draft of the NEP included a reduction of the nuclear energy program contemplated in the first draft, authorizing the construction of only three new plants in addition to the seven already under construction. This implied the withdrawal of authorization for six plants awaiting

\footnotetext{
${ }^{16}$ The attendance figures vary according to different sources, but the response was massive: between 15,000 and 50,000 people (La Gaceta del Norte 1976b; López Romo and Lanero Táboas 2010: 760).

${ }^{17}$ Property damage was assessed at several hundred million pesetas according to sources close to Iberduero (La Gaceta del Norte 1978c).
} 
approval at that time. The Minister of Industry supported this reduction by arguing that the earlier nuclear plans had been based on an accumulated annual economic growth of around $6 \%$ that had been reduced to $4 \%$. The new draft was the cause of bitter controversy between the Ministry and the private sectors involved in the nuclear program (El País 1978c).

The daily press also reflected the rising anti-nuclear environment. In May 1978, the newborn centerleft newspaper El País published an editorial entitled "Promises and dangers of nuclear energy" (El País 1978d). It criticized the huge investment planned for the construction of nuclear power plants (estimated at around 325,000 million pesetas). It criticized the government's commitment to nuclear energy as a means of limiting the dependence on oil, claiming that it ignored the potential hazards of environmental pollution or catastrophic accident.

A month later, the sociologist Mario Gaviria, one of the leaders of environmental activism in Spain, described "planning errors committed by the main electric companies between 1969 and 1972, when they decided on the nuclearization of Spain" (El País 1978e). According to Gaviria, the NEPs were ideological documents used to correct successive forecast errors by the electricity sector and to support investment by private companies in nuclear power plants. He also suggested that the underlying objective of the Plan, advocated by the Americans and supported by the Spanish electric and nuclear sector, was to replace oil with nuclear energy (El País 1978e).

The FAE emerged as the public representative of the nuclear sector in response to this negative environment for nuclear energy in Spain. The FAE made strong efforts to counteract the opposition through public interventions in the print media, radio and TV. Alfonso Álvarez Miranda, the president of the FAE, led these appearances in the media during the first half of 1978, with forthright statements that "saying no to nuclear energy, is saying yes to the recession and unemployment" and that "causes of opposition to nuclear power have no serious scientific basis but underlying emotional causes, as the memories of the atomic bombs dropped on Hiroshima and Nagasaki" (ABC 1978a). He also described the opposition to nuclear energy as more ideological than technical, and insisted that nuclear energy was necessary, safe and affordable (ABC 1978b). Hence, the nuclear sector strategy focused on the need for nuclear energy for economic development and attempted to delegitimize the opposition as "less technical" and prone to unfounded fears associated with the memories of Hiroshima and nuclear bombs tests. These arguments were similar to those propagated by other nuclear lobbies during the 1970s.

Besides the FAE, the nuclear option was strongly supported in this debate by other representatives of the private energy sector, such as the managers of oil and electric companies, as revealed in a "Survey among energy sector experts" published by $A B C$ in May $1978 .^{18}$

\footnotetext{
${ }^{18}$ The survey was conducted among five leading experts of the Spanish energy sector. These experts were Alfonso Alvarez Miranda, president of FAE; Emilio Sanz Hurtado, manager of the oil company Petroliber and member of the Technical Commission of the Minister of Economy for the drafting of the NEP; Roberto Centeno, manager of the energy company Campsa and also member of the Technical Commission of the Minister of Economy; Juan Alegre Marcet, president of Unesa (Association of Spanish electric companies), and Julio Calleja González-Camino, president of Hispanoil (another oil company). The survey comprised two questions: 1. Do you support nuclear energy? 2. Would you nationalize the sector? To the first question, all five answers were "yes", and in a categorical manner. For the second question, there was a more nuanced response, with 2 "yes" and 3 "no" (ABC 1978c).
} 
A draft of the second NEP was presented to Congress in July 1978, after major amendments to earlier drafts. According to El País, the positive reaction of the electrical and nuclear sectors indicated that the private sector had again won the battle (El País 1978f). However, the NEP failed to gain approval, and public debate on energy policy continued throughout the second half of 1978, with no changes in the arguments presented by each side (El Periódico de Catalunya 1978a).

The first turning point in the nuclear debate was prompted by the celebration of the Austrian referendum on nuclear energy on November 5 1978, related to approval for the start-up of the Zwentendorf Nuclear Power Plant (Hirsch and Nowotny 1977; Pelinka 1983: 253-261). The referendum resulted in a narrow majority against the Zwentendorf plan and represented an unexpected defeat for the European nuclear lobby as a whole. The right-wing newspaper $A B C$ published a special report on the possibility of a nuclear referendum in Spain (ABC, 1978d) that included statements by representatives of the nuclear sector (e.g., the FAE President and the Director of the Nuclear Energy Board) on the need for nuclear energy to ensure the economic development of the country (ABC, 1978e). The "bases of the anti-nuclear opposition" were described by the $\mathrm{ABC}$ editorial staff on the same page as: the incomplete or developing nature of the technology; ecological disruption and pollution; lack of economic viability; progressive restriction of freedoms to guarantee the security of nuclear facilities; higher concentration of economic and political power; and increasing foreign dependence in energy matters (ABC 1978f).

The FAE intensified its efforts to counteract the increasingly negative perception of the public and to support the nuclear option in the drafting of the new NEP. Besides the public appearances in the media, it set up a "Public Information Campaign" similar to those organized by the Industrial Forums in the USA, France and Switzerland and to the campaign launched by Foratom in the same year (Fórum Atómico Español 1978a: 8). One of the main features of the campaign was the creation of a Public Opinion Working Group focused on designing and carrying out opinion polls. According to the polling results obtained, nuclear energy was perceived as the most dangerous and most polluting option ${ }^{19}$. It was seen as something new and mysterious but with a bad reputation. In comparison to a poll by the Minister of Industry in 1975, the new polls revealed a worsening of the public image of the nuclear industry (Fórum Atómico Español 1978a: 8). Other activities of the Working Group included the compilation of favorable news clippings for sending to news agencies (Fórum Atómico Español 1978c: 3) and an "immediate response" service to counter stories or articles in the daily press that cast nuclear energy in a negative light (Fórum Atómico Español 1978d: 32-35). The public information campaign also involved the publication of documents and public reports advocating nuclear energy, the selection of audiences and topics for conferences or talks given by members of the FAE, and the achievement of media coverage for their presentations (Fórum Atómico Español 1978b: 24).

Further research is required to establish whether FAE's public information campaign was effective in changing the public perception of nuclear energy. However, one example of the limited success of FAE's attempts to reshape the debate on nuclear energy in Spain may be the objections to the NEP draft raised by

\footnotetext{
${ }^{19}$ The survey was carried out during January and February 1978 by the consulting agency AGEUROP (Fórum Atómico Español 1978a: 8-10).
} 
all political groups when it was discussed in Congress in December 1978, leading to the need for it to be redrafted once again (El Periódico de Catalunya 1978b).

\section{The Three Mile Island (TMI) accident and the decline of the nuclear industry in Spain}

The TMI accident is known as the first "major" accident in nuclear industry history. It occurred at TMI Power Plant in Pennsylvania, on March 28 1979. It represented a major shock to the nuclear industry, which had emphasized the safety of the plants as one of the main arguments in the pro-nuclear discourse during the 1970s. While the public health consequences of the accident remain controversial and have been described as "frustratingly ambiguous" (Walker 2000), consensus has been achieved on its major impact on the economy and on public opinion. According to the IAEA, the TMI accident was a significant turning point in the global development of nuclear power. ${ }^{20}$ However, it has been claimed the accident did not initiate the demise of the nuclear power industry, as many planned nuclear power plants in USA had already been canceled between 1973 and $1979 .^{21}$

The first reactions to the accident came from the US Nuclear industry representatives. In a display of humility and concern, the president of the AIF Carl Walske declared: "I thought we were better than that before the accident happened". In addition, William J. Lannouette, a journalist specialized in nuclear power, reported that some of them were "stunned and dispirited" (Walker 2006: 222). The nuclear sector as a whole decided to take action to deal with the crisis. The AIF established a committee to coordinate communication activities, realizing that this accident could cause severe damage to the nuclear industry worldwide (Walker 2006: 223).

In Spain, the impact of the accident on public opinion was a matter of great concern to FAE leaders and the pro-nuclear lobby. Fears were also raised about its effects on the prospects for the NEP, which had yet to be approved and remained under public debate (Fórum Atómico Español 1979b: 5-7). At a conference held in Bilbao on the day after the accident, the new President of FAE, José Antonio Gallego Gredilla, stated that they had to stick to the "cold language of science, facts, and logic" against the "emotional and passionate arguments" used by anti-nuclear protestors (La Gaceta del Norte 1979).

During 1979, some major anti-nuclear demonstrations took place in Spain against the NEP and in favor of a nuclear moratorium, especially in Barcelona (El Periódico de Catalunya 1979a/ 1979b). Days after the accident, in April 1979, a group of Spanish environmental organizations publicly called for the immediate cessation of the Spanish nuclear development program and a five-year moratorium on building nuclear power plants to provide time for a thorough debate on the risks. The group claimed that Spain could meet its energy needs without recourse to nuclear energy and demanded that the current NEP draft be

\footnotetext{
${ }^{20}$ From 1963 to 1979 , the number of reactors under construction globally increased every year except in 1971 and 1978 (IAEA 2012). However, following this event, the number of reactors under construction in the US declined every year from 1980 to 1998. Many similar Babcock and Wilcox reactors on order were canceled. Eventually, 51 American nuclear reactors were canceled from 1980 to 1984 (EIA 1983).

${ }^{21}$ As a result of post-oil-shock analysis and conclusions of overcapacity, many planned nuclear power plants had already been canceled between 1973 and 1979 due to more stringent Federal requirements, more strident local opposition and significantly lengthened construction times (Hertsgaard 1983: 95-97).
} 
withdrawn from Congress and replaced by a transitional strategy that excluded nuclear energy (El País 1979a).

The nuclear industry sector feared that the impact of the accident would focus the debate exclusively on nuclear policy. There were also concerns about the plants under construction and those with prior authorization sector, given the support for the nuclear moratorium announced by the Socialist and Communist parties (Fórum Atómico Español 1979a: 17-20). The chairman of the Congress Energy Committee, Josep Maria Triginer, claimed that the accident could even reinforce the Spanish nuclear program if it led to improvements in safety measures, although he admitted that it could ultimately lead the government to reconsider the entire nuclear policy (El Periodico de Catalunya 1979c).

The government accepted the opposition's proposals to improve the security and control of nuclear facilities, but the new Minister of Industry and Energy, Carlos Bustelo ruled out any consideration of a moratorium (ABC 1979). FAE representatives and the Working Group on Public Opinion published informative notes detailing the technical causes of the accident. However, a print media analysis carried out by the FAE yielded very disappointing results, because the nuclear sector had expected a less aggressive treatment of the issue by the media (Fórum Atómico Español 1979b: 7).

The new NEP was eventually approved by Congress on July 27 1979. The absence of previsions for the massive nuclearization of the country is attributable to the active civil opposition to the plan, the TMI accident, and delays in the construction of the new nuclear power plants due to the immense investment costs involved, among others (Cuerdo 1999: 161-178). Priority was given to local resources, such as coal and hydraulic power, as had been proposed in the second draft of the Plan. The approved NEP gave nuclear energy a place as a complementary source for completing the energy supply, but only under "the strictest security measures" (El País 1979b). This was seen as a victory for the environmentalist and anti-nuclear movements in Spain (Fernández 1999: 302) and a discouraging decision for the nuclear sector and the FAE. In late March 1984, the Socialist government approved a moratorium, and only 11 out of the 37 originally planned commercial nuclear reactors (including 20 already licensed) were finally built in Spain.

\section{Conclusion}

Although nuclear energy had been a controversial issue since the 1950s, the expansion of the nuclear industry during the 1960s and 1970s stimulated the growth of anti-nuclear movements and brought the nuclear debate into the public arena. Despite the complexity of the international anti-nuclear scenario in the late 1970s, several general trends can be identified, including the intensification of the protest as the growth of nuclear programs increased and the coalition of different interest groups against nuclear energy. Nuclear industrial associations emerged and played a key role in advocating nuclear energy with varying degrees of support from the national governments.

As in other countries developing a nuclear program, the FAE took a leading role as representative of the Spanish nuclear sector. The lack of democracy in the 1960s reduced the importance and public visibility of anti-nuclear movements. Not surprisingly, therefore, FAE's concerns about public opinion emerged later 
than in other countries. By the mid-1970s, the combination of an intense anti-nuclear struggle and growing calls for democracy in Spain led the FAE to enter the public arena with different communication strategies. Their main arguments included the need for nuclear power to meet increasing energy needs, the problems of coal and alternative energy sources, and the high safety record of nuclear power. Their strategy was to oppose anti-nuclear claims on nuclear costs, safety and waste management.

Anti-nuclear protests peaked in Spain in the late 1970s during the long debate before approval of the second NEP in July 1979, confronting the pro-nuclear discourse with warnings about the potential dangers and the enormous investment required. The anti-nuclear movement in Spain was heterogeneous and highly influenced by regionalist and nationalist movements and by the demands for democracy, which gave antinuclear protests in Spain certain distinctive features. The first NEP approved in 1975 envisaged what was perceived at the time as the nuclearization of Spain. After the first democratic elections in Spain in 1977, the so-called Pactos de la Moncloa generated a political commitment to mid-term energy planning resulting in the second 10-year NEP (1977-1987). The public debate on nuclear energy taking place in the late 1970s around the drafting of the new NEP paralleled a deterioration of the public image of the nuclear industry, which was exacerbated by the results of the 1978 Austrian referendum on nuclear energy and especially by news of the TMI accident. In fact, the impact of the TMI accident appears to have been crucial in persuading the Spanish government to abandon their plan for nuclear energy to be the main energy source, as eventually embodied in the 1979 NEP. From 1978 onwards, the FAE mounted a highly active public campaign to counteract the increasingly negative perception of nuclear energy in Spanish public opinion. The campaign, probably unrivalled in any other Spanish industrial sector, was similar to those launched by nuclear lobbies in the USA and the rest of Europe. The final version of the 1979 NEP was perceived by the FAE and the nuclear sector as a bitter defeat and by the Spanish environmental and anti-nuclear movements as a sweet victory.

\section{References}

ABC. 1978a. "Hay que ahorrar energía y reestructurar el sector”. April 25.

ABC. 1978b. "Clausura del Seminario sobre política energética”. June 14.

ABC. 1978c. "Opiniones en ABC sobre energía nuclear”. May 19.

ABC. 1978d. José María Fernández Rúa, “Hacia el referéndum nuclear”. December 20.

ABC. 1978e. José María Fernández Rúa, “La energía nuclear es una solución viable y económica” (Entrevista con Manuel López Rodríguez). December 20.

ABC. 1978f. Editorial staff, "Bases de la oposición antinuclear” December 20.

ABC. 1979. "Expectación ante el debate parlamentario sobre energía". May 5.

Akaha, Tsuneo. 1985. Japan's Three Nonnuclear Principles: A Coming Demise? Peace \&Change 11/1: 75-89.

Anes, G., S. Fernandez Plasencia and J. Temboury Villarejo. 2001. Endesa en su historia (1944-2000). Madrid: Fundación Endesa.

Balogh, Brian. 1991. Chain reaction: Expert debate and public participation in American commercial nuclear power, 1945 - 
1975. Cambridge: Cambridge University Press.

Barca Salom, Francesc X. 2005. Nuclear power for Catalonia: the role of the Official Chamber of Industry of Barcelona, 1953-

1962. Minerva 43: 163-181.

Bigas, Jordi. 1991. El ecologismo en el Estado Español. Ecología Política 93: 91-99.

British Nuclear Energy Society. 1956. Symposium on nuclear energy - Nuclear reactors for power generation. Nuclear Future, $5 / 3$.

Cabal, Esteban. 1996. Historia de los verdes. Madrid: Mandala Ediciones.

Caro, Rafael, Manuel López Rodríguez, and Francisco Vighi.1995. Historia Nuclear de España. Madrid: Sociedad Nuclear Española.

Costa, Pedro. 1976. Nuclearizar España. Madrid: Los Libros de la Frontera.

Cuerdo, Miguel. 1999. Evaluación de los Planes Energéticos Nacionales en España (1975-1998). Revista de Historia Industrial 15: $161-178$.

Damian, Michael. 1992. Nuclear power: The ambiguous lessons of history. Energy Policy, 20/7: 594-696.

Davidon, Ann Morrisett. 1979. The US antinuclear movement. Bulletin of the Atomic Scientists 35/10: 45-49.

De la Torre, Joseba and Maria del Mar Rubio Varas. 2014. El Estado y el desarrollo de la energía nuclear en España, c. 19501985, No 1403, Documentos de Trabajo (DT-AEHE), Asociación Española de Historia Económica.

El País. 1978a. “Acuerdo sobre la necesidad de reelaborar el Plan Energético de Industria”. January 14.

El País. 1978b. “El ministro de Industria se opone a determinadas propuestas del Plan Energético”. February 14.

El País. 1978c. “Oposición de los intereses privados a la reducción del programa nuclear”. May 6.

El País. 1978d. Editorial Board, "Promesas y peligros de la energía nuclear”. May 20.

El País. 1978e. Mario Gaviria, "Los planes energéticos trucados”. June 27.

El País. 1978f. “Cambios sustanciales en el Plan Energético Nacional enviado a las Cortes”. July 1.

El País. 1979a. “Exigen la paralización del programa nuclear español”. April 4.

El País. 1979b. "Resoluciones aprobadas sobre el Plan Energético Nacional”. July 27.

El Periódico de Catalunya. 1978a. Editorial. October 26.

El Periódico de Catalunya. 1978b. “A nadie le gusta el Plan Energético del Gobierno”. October 27.

El Periódico de Catalunya. 1979a. "Barcelona será hoy una ciudad antinuclear”. March 11.

El Periódico de Catalunya. 1979b. "Barcelona vive una “diada" ecologista". March 12.

El Periódico de Catalunya. 1979d. Josep Maria Triginer, "El accidente de Harrisburg podría incluso reforzar el programa nuclear". April 3.

Energy Information Administration (EIA). 1983. Nuclear Plant Cancellations: Causes, Costs, and Consequences, DOE/EIA0392 (April 1983).

European Nuclear Society, Deutsches Atomforum, eds. 1979. Acceptance of nuclear power. Essen: Vulkan-Verlag.

Fach, Wolfgang and Edgar Grande. 1992. Emergent rationality in technological policy: Nuclear energy in the Federal Republic of Germany. Minerva 30/1: 14-27.

Falk, Jim. 1982. Global Fission: The Battle Over Nuclear Power. New York: Oxford University Press.

Fernández, Joaquín. 1999. El ecologismo español. Madrid: Alianza.

Forgan, Sophie. 2003. Atoms in Wonderland. History and technology 19/3:177-196.

Fórum Atómico Español. 1962. Boletín Informativo $\mathrm{n}^{\circ} 1$.

Fórum Atómico Español. 1966a. Boletín Informativo no 22. 
Fórum Atómico Español. 1966b. Boletín Informativo no 23.

Fórum Atómico Español. 1966c. Boletín Informativo $\mathrm{n}^{\mathrm{o}} 24$.

Fórum Atómico Español. 1966d. Boletín Informativo $\mathrm{n}^{\mathrm{o}} 25$.

Fórum Atómico Español. 1966e. Boletín Informativo no 26.

Fórum Atómico Español. 1976. Boletín Informativo no 50.

Fórum Atómico Español. 1977a. Boletín Informativo n ${ }^{\circ} 51$.

Fórum Atómico Español. 1977b. Boletín Informativo $\mathrm{n}^{\circ} 52$.

Fórum Atómico Español. 1977c. Actas XIV Jornadas Nucleares. La sociedad y la energía nuclear. Madrid: Fórum Atómico Español

Fórum Atómico Español. 1978a. Boletín Informativo n53.

Fórum Atómico Español. 1978b. Boletín Informativo nº54.

Fórum Atómico Español. 1978c. Boletín Informativo n55.

Fórum Atómico Español. 1978d. Boletín Informativo n56.

Fórum Atómico Español. 1979a. Boletín Informativo nº6.

Fórum Atómico Español. 1979b. Boletín Informativo nº67.

Freeman, Jo and Victoria Johnson eds. 1999. Waves of Protest: Social Movements Since the Sixties. Lanham: Rowman and Littlefield.

Giugni, Marco. 2004. Social Protest and Policy Change: Ecology, Antinuclear, and Peace Movements in Comparative Perspective. New York: Rowman \& Littlefield Publishers.

Gómez Mendoza, A. 2007. Electra y el Estado : la intervención pública en la industria eléctrica bajo el franquismo. Navarra: Cizur Menor.

Goodman, L. 1961. Some atomic reactor accidents. Partial list of accidents involving radiation in Atomic Energy. Washington: Atomic Technical Comittee, UID-AFL-CIO.

Gottlieb, Robert .2005. Forcing the Spring: The Transformation of the American Environmental Movement, Washington: Island Press.

Häfele, Wolf. 1974. Hypothetically and the new challenges: The pathfinder role of nuclear energy. Minerva 12/3: 303-322.

Hertsgaard, Mark. 1983. Nuclear Inc. The Men and Money Behind Nuclear Energy. New York: Pantheon Books.

Hetch, Gabrielle. 1996. Rebels and Pioneers: Technocratic Ideologies and Social Identities in the French Nuclear Workplace, 1955-69. Social Studies of Science 26: 486-488.

Hewlett, Richard G. and Jack Holl. 1989. Atoms for Peace and War. 1953-1961. Los Angeles: University of California Press.

Hewlett, Richard G. 1990. The new world, 1939 - 1946. A history of the United States Atomic Energy Commission. Berkeley: University of California Press.

Higuchi, Toshihiro. 2008. An Environmental Origin of Antinuclear Activism in Japan, 1954-1963: The Politics of Risk, the Government, and the Grassroots Movement. Peace \& Change 33/3: 333-366.

Hirsch, Helmut, and Helga Nowotny. 1977. Information and opposition in Austrian nuclear energy policy. Minerva 15/3-4: 316334.

International Atomic Energy Agency (IAEA). 2012. 50 Years of Nuclear Energy.

http://www.iaea.org/About/Policy/GC/GC48/Documents/gc48inf-4_ftn3.pdf. Retrieved December 29 2008. Accessed October 102013.

Kenward, Michael. 1976. California Dreaming. New Scientist 70/1003: 523. 
Kitschelt, Herbert P. 1986. Political Opportunity Structures and Political Protest: Anti-Nuclear Movements in Four Democracies. British Journal of Political Science 16/1: 57-85.

Kriesi, Hanspeter, Ruud Koopmans, Jan Willem Duyvendak, and Marco G. Giugni. 1995. New social movements in Western Europe. A comparative analysis. Minneapolis: Minnesota University Press.

Krige, John. 2006. Atoms for Peace, Scientific Internationalism, and Scientific Intelligence. Osiris 21: 161-181.

La Gaceta del Norte. 1976a. August 30.

La Gaceta del Norte. 1976b. August 31.

La Gaceta del Norte. 1978a. March 3.

La Gaceta del Norte. 1978b. March 18.

La Gaceta del Norte. 1978c. March 20.

La Gaceta del Norte. 1979. March 29.

Lewis, Richard S. 1972. The Nuclear-Power Rebellion: Citizens vs. the Atomic Industrial Establishment. New York: Viking Press.

López Romo, Raúl. 2008. Tiñendo la patria de verde y violeta. Las relaciones del nacionalismo vasco radical con los movimientos antinuclear y feminista en la Transición, in Ayeres en discusión: temas clave de Historia Contemporánea hoy coord. María Encarna Nicolás Marín and Carmen González Martínez. Murcia: Universidad de Murcia.

López Romo, Raúl and Daniel Lanero Táboas. 2010. Antinucleares y nacionalistas. Conflictividad socioambiental en el País Vasco y la Galicia rurales de la transición. Historia Contemporánea 43: 749-777.

López Romo, Raúl. 2011. ¿Democracia desde abajo? Violencia y no violencia en la controversia sobre la central nuclear de Lemóniz (Euskadi, 1976-1982). Historia, Trabajo y Sociedad 2: 91-117.

Megara, John. 2006. Dropping nuclear bombs on Spain. The Palomares accident of 1966 and the U.S. airbone alert. Florida State University.

Mez, Lutz, Mycle Schneider, and Steve Thomas (eds.). 2009. International Perspectives of Energy Policy and the Role of Nuclear Power. Essex: Multi-Science Publishing Co. Ltd.

Mills, Stephen, and Roger Williams. 1986. Public Acceptance of New Technologies. New York: Routledge.

Ministerio de Industria y Energía. 1978. Plan Energético Nacional 1978-1987. Madrid: Ministerio de Industria y Energía, Servicio de Publicaciones.

Mora Ticó, Pere. 2012. El moviment ecologista a Catalunya: el seu origen, evolució i inserció a la societat catalana. Barcelona: Universitat Autònoma de Barcelona.

Morris, A., and R.H. Engelken. 1973. Safety Experience in the Operation of Nuclear Power Plants, IAEA-SM-169/147. In Principles and Standards of Reactors' Safety. IAEA. Vienna: IAEA, 1973.

Ordóñez, Javier, and José Manuel Sánchez-Ron. 1996. Nuclear Energy in Spain. From Hiroshima to the Sixties. In National Military Establishments and the advancement of Science and Technology eds. Paul Forman and José Manuel Sánchez Ron, 185-213. Dordrecht: Kluwer.

Patterson, Walter C. 1986. Nuclear Power, London: Penguin Books.

Pelinka, Anton. 1983. The nuclear power referendum in Austria. Electoral Studies 2: 253-261.

Presas i Puig, Albert. 2005. Science on the periphery. The Spanish reception of nuclear energy: an attempt at modernity? Minerva: 43: 197-218.

Presas i Puig, Albert. 2009. Globalization through radiation: a reactor for everyone. In A Comparative Study of European Nuclear Energy Programs, ed. Albert Presas i Puig. Berlin: Preprints Max Planck Institute. 
Preston, Paul. 1986. El triunfo de la democracia en España: 1969-1982. Barcelona: Plaza y Janés.

Romero, Ana, and José Manuel Sánchez-Ron. 2001. Energía Nuclear en España: de la JEN al CIEMAT. Madrid: CIEMAT.

Romero de Pablos, Ana. 2012. Energía nuclear e industria en la España de mediados del siglo xx. Zorita, Santa María de Garoña y Vandellòs 1. In La física en la dictadura. Físicos, cultura y poder en España (1939-1975), eds. Nestor Herran and Xavier Roqué. Barcelona: Universitat Autónoma de Barcelona, Servei de Publicacions.

Rudig, Wolfgang. 1990. Anti-nuclear Movements: A World Survey of Opposition to Nuclear Energy, Harlow: Longman.

Sánchez-Vázquez, Luis. 2010. La legitimación de la energía nuclear en España: el Fórum Atómico Español (1962-1979). Granada: University of Granada.

Sánchez-Vázquez, Luis. 2012. Uranio, reactores y desarrollo tecnológico: relaciones entre la Junta de Energía Nuclear y la industria nuclear española (1951-1975). In La física en la dictadura. Físicos, cultura y poder en España (1939-1975), eds. Nestor Herran and Xavier Roqué. Barcelona: Universitat Autónoma de Barcelona, Servei de Publicacions.

Shawki, Noha. 2010. "Political Opportunity Structures and the Outcomes of Transnational Campaigns: A Comparison of Two Transnational Advocacy Networks", Peace \&Change, 35/3: 381-411.

Surrey, John, and Charlotte Hugget. 1976. “Opposition to nuclear power. A review of international experience”, Energy Policy, 4/4: 286-307.

Taylor, Richard. 1994. Against the Bomb: The British Peace Movement, 1958-1965. Oxford: Clarendon Press.

Walker, J. Samuel. 2000. Permissible Dose. A History of Radiation Protection in the Twentieth Century. Berkeley: University of California Press.

Walker, J. Samuel. 2006. Three Mile Island: A Nuclear Crisis in Historical Perspective. Berkeley: University of California Press. Weart, Spencer R. 1988. Nuclear Fear: a history of images. Cambridge: Harvard University Press.

Wellock, Thomas Raymond. 1998. Critical masses: opposition to nuclear power in California, 1958-1978. Madison: Univ of Wisconsin Press.

Yamazaki, Masakatsu. 2009. Nuclear energy in postwar Japan and anti-nuclear movements in the 1950s. Historia Scientarium (Tokyo) 19/2: 132-145.

Young, Nigel.1983. The Contemporary European Anti-Nuclear Movement: Experiments in the Mobilization of Public Power. Peace \& Change 9/1: 1-16.

Ysàs, Pere. 2007. ¿Una sociedad pasiva? Actitudes, activismo y conflictividad social en el franquismo tardío. Ayer, 68 (2007): 31-57. 


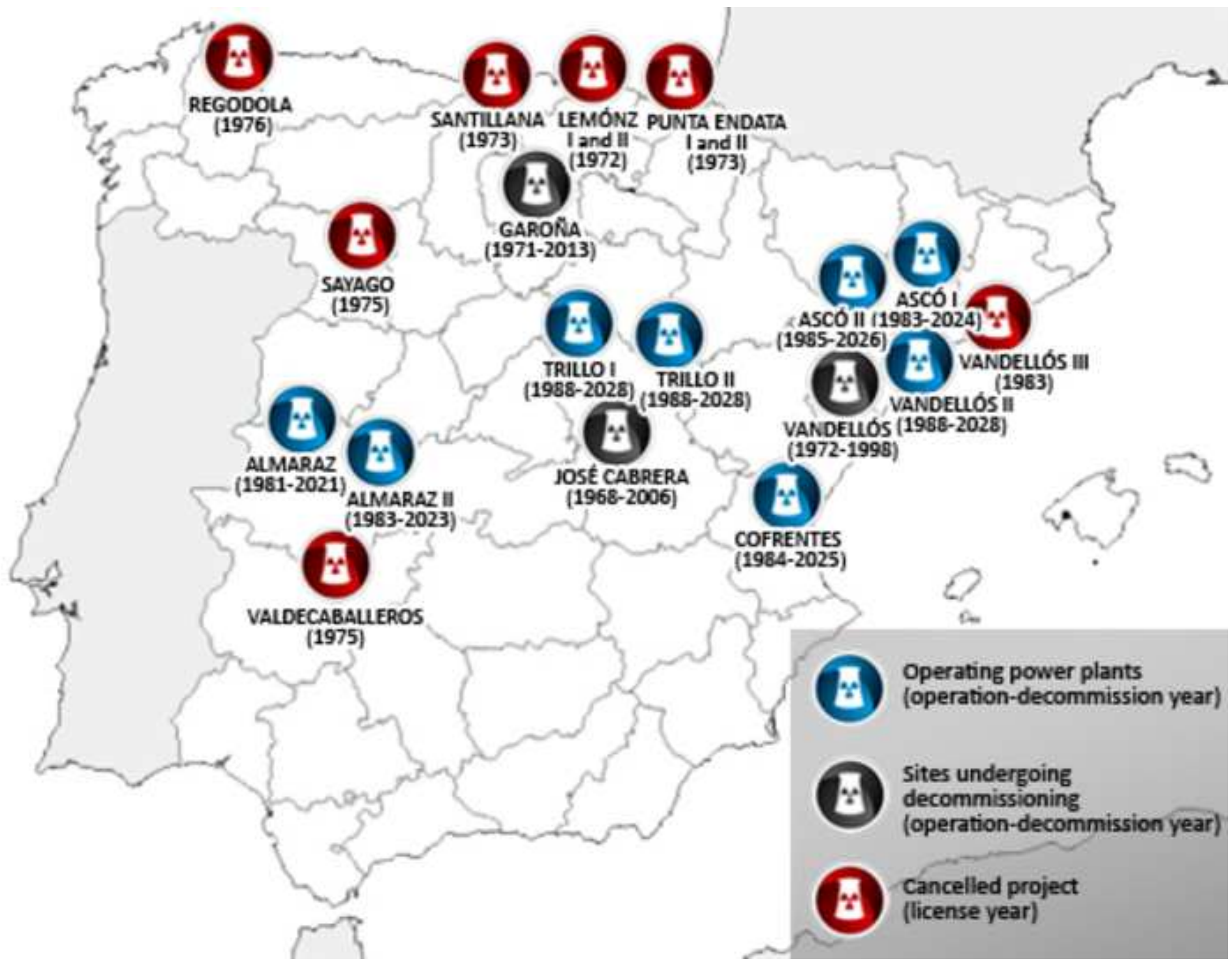


Responses to reviewers' comments

Reviewer \#1:

Comment 1 . The 1955 conference in Geneva is misnamed: It was the International Conference on the Peaceful Uses of Atomic Energy.

Response: We now give the correct name of the conference.

Comment 2. Far more substantially, the author gives us no idea at all of the social make-up of the protest movement in Spain. This is a serious omission and needs to be rectified. Nor are we told much about the regional diversity of that protest movement. We are made aware of ETAs violent opposition to nuclear power, but we are told little or nothing about the peaceful protesters in the Basque region, in Catalonia, and in the capital, Madrid - for example. Granted the importance of regional differences in Spain this is a nuance that needs to be included in a more detailed analysis of just who was against nuclear power, what forms their protest took, and how their opposition was managed by the authorities (apart from eventually backing off from their earlier strong support for the nuclear option).

Response: We agree that it would be very helpful to provide further information on the regional diversity of the protest movement. We have included a new paragraph in section 5 [The late anti-nuclear awakening in Spain: From Palomares (1966) to the "Long Anti-nuclear March" (1974-1977)] exploring how opposition to nuclear power plants became a valuable tool for the nationalist movements to expand their presence in the public space in terms of the political opportunities presented by mass mobilizations. Moreover, we have provided further details on the protests carried out in the Basque Country and Catalonia.

We very much appreciate the work put in by this reviewer and the positive remarks.

\section{Reviewer \#2:}

Comment 1. The text first describes the American and European anti-nuclear movement, before introducing the Spanish case. However, it fails to take into consideration the fact that the latter was active during a brutal dictatorship which prohibited any expression of opposition or questioning of the regimes policies in any shape or form; in this case its political and economic policies. This aspect, which, when it is discussed in the text, is given insufficient clarity and importance, totally conditioned not only the policies of Francos regime with regard to nuclear development, but also the strategies of the Spanish anti-nuclear movement. The reality of the Spanish political situation in the 1960s, as well as in the 1970s and 1980s, makes it impossible to refer to a homogeneous "Spanish" anti-nuclear movement. The processes of national liberation (Catalonia, the Basque Country, later terrorist acts), open opposition to the dictatorship (far-left parties and non-parliamentary movements), the indecision and subsequent acceptance by the Spanish Communist Party (PCE) and the Spanish Socialist Party (PSOE until the 80s) of the nuclear option, the anti-NATO movement, etc. make the Spanish case one that is difficult to compare with the rest of the international anti-nuclear movements in the way that the article seems to suggest. It is only later that the dynamics of the antinuclear and pro-peace movement (against NATO) can be compared with other social movements in Europe: its (albeit indecisive) influence on the nuclear moratorium and the socio-cultural impact of the campaign against Spain joining NATO and against compulsory military service.

In this regard, there are a number of publications that the author should take into account: 
Raúl López Romo, (2008) «Tiñendo la patria de verde y violeta. Las relaciones del nacionalismo vasco radical con los movimientos antinuclear y feminista en la Transición", in: Ayeres en discusión: temas clave de Historia Contemporánea hoy", coord. by María Encarna

Nicolás Marín, Carmen González Martínez, 2008.

Raúl López Romo, Daniel Lanero Táboas. Antinucleares y nacionalistas. Conflictividad socioambiental en el País Vasco y la Galicia rurales de la transición. Historia Contemporánea 43: 749-777, 2010.

Ladislao Martínez. El movimiento ecologista. La lucha antinuclear y contra el modelo energético en España. Mientras tanto, №. 91-92, 2004, pp. 83-106.

Pere Mora Ticó. El moviment ecologista a Catalunya: el seu origen, evolució i inserció a la societat catalana. Doctoral thesis. Universitat Autònoma de Barcelona Barcelona, September 2012.

Response: We are very grateful for the information and references on the regional diversity of the protest movement. We have included a new paragraph in section 5 exploring how opposition to nuclear power plants became a valuable tool for the nationalist movements to expand their presence in the public space in terms of the political opportunities presented by mass mobilizations. Moreover, we have provided further details on the protests carried out in the Basque Country, Galicia and Catalonia. We have also commented on the way in which the Francoist repressive system affected the protest in Spain.

We have also completed the section in which the Lemoniz incident is described [Section 6: Lemóniz conflict, the drafting of the second National Energy Plan and the reaction of the Spanish Atomic Forum (1978)]. The papers by López Romo on the Lemoniz conflict cited by the reviewer proved highly valuable for this purpose, deepening the analysis of the conflict, exploring the links between ETA and the anti-nuclear movement in the Basque Country, and examining further reactions of the civil society to the event.

We are grateful to the reviewer for the suggested reading on these topics, improving understanding of the links between the nationalist protest and the anti-nuclear movements, especially in the Basque Country and Catalonia.

Comment 2. Moreover, it is not sufficient to analyse newspapers published in Madrid, such as $A B C$ and El País, in order to understand the process. It is essential also to include publications by the antinuclear movement, such as: BIEN - Boletin de Información sobre Energía Nuclear. Comité Antinuclear de Catalunya. A good introduction can be found in: Alemany, J. (1995). "El moviment ecologista a través de les seves publicacions". Catalonia Culture, 42, pp. 32-35. In addition, newspapers which reflect regionalist and nationalist perspectives such as Punto y Hora de Eukal Herria, Egin, La Gazeta del Norte, Tele/eXpres, Mundo Diario, Avui, El Periódico de Catalunya should be consulted.

Response: We have now included analyses of two regional newspapers: La Gaceta del Norte and El Periódico de Catalunya. Unfortunately, we have been unable to gain access to the other suggested sources. 
Comment 3. Furthermore, the structure of the Spanish nuclear programme during the years of the dictatorship deserves a more in-depth analysis than that put forward by the author. The infighting within the regime itself during the period of the autocracy, as exemplified by Suanzes, its main ideologue, and Otero Navascués, the head of the nuclear programme, are key to understanding the success of the change of orientation proposed by the "technocrats" and the technological options of the electrical companies, but this is not described in the article. Studies devoted to the history of the electrical companies involved are also of interest:

Anes, G. y Gómez Mendoza, A.. 2006. "Un siglo de luz: historia empresarial de Iberdrola". [Madrid]: Iberdrola.

Anes, G., S. Fernandez Plasencia, J. Temboury Villarejo. 2001. "Endesa en su historia (19442000)". Fundación Endesa.

Gómez Mendoza, A. 2007. "Electra y el Estado: la intervención pública en la industria eléctrica bajo el franquismo." Cizur Menor Navarra.

José Luis Ramos- Gorostiza, Luis Pires-Jiménez. "Spanish Economists Facing Indicative Planning in the 1960s." SPE/1-2009: 77-108.

Joseba De la Torre , Mar Rubio, 2013. El Estado y el desarrollo de la energía nuclear en España, c. $1950-1985$.

Response: We are grateful for this comment and for the valuable bibliographic recommendations. We have added new information and citations on this issue in section 4 [The nuclear industry in Spain (1962-1976)]

We have included a new paragraph on the relevance of conflicts and divergences within the Spanish Government in order to understand how the view proposed by the technocrats was reinforced. We have also expanded our description of the process of development of the Spanish nuclear program, based on information provided by the paper of De la Torre and Rubio (2013). Furthermore, we have completed the details of the electric companies involved in the nuclear sector, using data published by Gómez Mendoza (2007) and Anes et al. (2001).

We are very grateful for the insights and recommendations of this reviewer, which have led to major improvements in our paper. 